\title{
Symbolic participation in community-based tourism in Kelimutu National Park, Ende, East Nusa Tenggara
}

\author{
Josef Alfonsius Gadi Djou ${ }^{1}$, M. Baiquni ${ }^{2}$, Tri Widodo ${ }^{3}$, Chafid Fandeli ${ }^{4}$ \\ ${ }^{I}$ Tourism Study Program, Graduate School Program, University of Gadjah Mada, Jl. Teknika Utara, Pogung \\ Yogyakarta, Indonesia \\ ${ }^{2}$ Faculty of Geography, University of Gadjah Mada, Yogyakarta, Indonesia \\ ${ }^{3}$ Faculty of Economics and Business, University of Gadjah Mada, Yogyakarta, Indonesia \\ ${ }^{4}$ Faculty of Forestry, University of Gadjah Mada, Yogyakarta, Indonesia
}

\begin{abstract}
Community participation in tourism development has been received a lot of attention. A research with qualitative and quantitative combination has performed to describe the community participation in ecotourism development in Kelimutu National Park, East Nusa Tenggara, Indonesia. This research involves 362 respondent and 36 informants to describe the community participation in ecotourism program. This research shows that community participation was implemented in symbolic participation form. Community involvement practically only used as a conditions to get program approval. As a result, the majority of local community (48\%) fell less involved in ecotourism development, especially in natural resources usage. Respondents has less concern to support attraction, accessibility and amenity preservation (49.2\%) of tourism. It seems to be related to the respondent's conditions, in which respondent state tourism in Kelimutu not contribute to the society prosperity. Since there are significant impacts of symbolic community participation, there are important to perform more strategy and approach to increase the participation level of the community in ecotourism program. The synergy among stakeholder to increase the community-based ecotourism with active community participation was needed.
\end{abstract}

Keywords: Ecotourism, community based tourism, local participation, sustainable tourism

\section{Introduction}

Recently ecotourism has been identified as an important tourism programs to support local development and conservation. The significant role of ecotourism for local economic development has been demonstrated in numerous countries. In such a case, the success has been identified depend on the planning and implementation. Scholar point out that proper planning should be able to invite local people to participate actively in ecotourism planning. The indicator for the success has been measured through the economic development and increasing human prosperity. The market segment of ecotourism is growing and there are opportunities to enhance local economic development through ecotourism development [1] [2] [3] [4] [5].

Remotes area with abundance natural resources is one of the magnets for ecotourism market. Therefore, the development of ecotourism in Indonesia is important. The development of ecotourism in numerous national parks in Indonesia has been viewed as one of the significant strategy to improve human being. Through ecotourism, there are opportunities for local economic growth. Ecotourism in national park provides jobs and reduce forest disturbance by local people [3] [4] [5].

Challenges for ecotourism development related to the degree of community participation. It is especially important among developing countries, where human resources capacity significantly contributes to the planning quality. Poor planning lead to the problems of community involvement in ecotourism program, and therefore the economic objectives of ecotourism to improve local income and provides jobs fail. There also social aspect related to the impact of low involvement of local people in ecotourism development [6] [7] [8]. In the recent trend in sustainable development vision, sustainable tourism will contributes to the sustainable development in Indonesia [9] [10]. The ecotourism in Kelimutu National Park was initiated in March 31, 1982 by promoting three main attractions, namely natural attraction, cultural attraction and man-made attraction. The ecotourism program in Ende take place in an area about $\pm 5,356.5 \mathrm{Ha}$ at elevation 1,000-2,000 $\mathrm{m}$ asl. Natural attraction includes Three color lake (locally called Danau Triwarna, encompasses three lakes namely Tiwu Ata Bhupu, Tiwu Koo Fai Nuwa Muri and Tiwu Atapolo), 180 species of flora and 91 species of fauna. Cultural attraction includes 16 traditional villages (kampung adat) and 22 kinds of local-traditional rituals. The manmade attraction includes rural tourism, arboretum, insectariums, herbarium, agro-ecotourism, and Dutch colonial building. In the development process, the ecotourism programs has involved local community participation in 18 villages surrounding Kelimutu National Park. These villages distributes at five sub-regency in Ende Regency, namely Kelimutu, Ndona, Ndona Timur, Wolojita and Detusoko. These villages have been involved to the numerous programs related to the ecotourism development. Since the ecotourism development 
has been claimed to involve actively community in its programs, the tourism activity in such villages referred as community-based ecotourism. The development of ecotourism in Kelimutu National Park seems to be unable to meets its objectives. There are poor implementation of ecotourism principles. There are problems and difficulties for ecotourism principles. As a CBT program, tourism in Kelimutu National Park was developed following CBT concept, in which local community involvement become the focus of tourism development program [11] [12]. There are empirically observed that the participation far from the reality. The local community involvement seems to be less. Conceptually, community-based tourism evolve as a respond to the rapid development of mass tourism which are contributes to the negative impact to cultural and natural aspect of local community. There is several aspect which are related to CBT, namely (a) local community participation to control tourism development (b) there are benefits which are directed to community, and (c) the characteristics is empowerment. CBT is the tourism forms that has three important basic aspect, namely (a) community involvement; (b) equal economical access, and (c) political empowerment to support community as a decision makers [7] [8] [10] [11] [12] [13]. Community based tourism related to the sustainability of social and culture of local community [6]. CBT in the form of tourism business in which the industry was managed, owned and addressed to community. Scholar point out that CBT is tools for community development [10] [11]. The vision of CBt relevant with the conservation program in national park, and therefore CBT is the complementary programs in national park to support biodiversity conservation and local people prosperity [4] [5] [8]. The research aim to describe the community participation in ecotourism development in Kelimutu National Park, East Nusa Tenggara, Indonesia

\section{Study area}

\section{Methodology}

Field survey was done at four villages, namely Pemo, Waturaka, Koanara and Woloara.These villages administratively belongs to Kelimutu district of Ende Regency, East Nusa Tenggara. In the perspectives of Kelimutu National Park Management, these villages located at the nearest area of core zone of Kelimutu National Park. Therefore, the sustainable development issues of these area to support conservation in Kelimutu National Park has been considered important. Kelimutu National park is the important sites for semi-arid biodiversity conservation in Eat Nusa Tenggara. The landscape of Kelimutu has been identified for future tourism development [14]. In order to describe to local people participation in tourism implementation, questioners was distribute to the 362 respondents in Pemo, Waturaka, Koanara and Woloara villages. Number of respondent was calculated following Slovin formula. In depth interviews was done by interviewing informant. Number of informant was 36 from 4 villages. The techniques to select informant was following snowball sampling. In order to get more comprehensive understanding about people participation, there are also participatory observation techniques was implemented. The secondary data and literature document was collected from numerous sources, including national park and local government library.

\section{Reliability and validity test}

Reliability and validity test was performed following four steps. Firstly, construct test and dimension to all quantitative data (362 quesioner) according to proposed hypothesis. Reliability was measured though expert analysis, including antropologist, sociologist, and ecotourism expert, while validity test was measured using convergent and discriminate which are generated from items cluster. Secondly, pre-test to the questionnaire was performed about $10 \%$ of the total response (362 responden). This test was performed to identify the consistency (reliability) and precisity (validity) of questionnaire statements and its indicators. Thirdly was questioner improvement after pre-test, and forth was justification of all questionnaire which are used in the survey. In order to draws the model of participation, the relationship between variables was established using Structural Equation Modeling techniques.

\section{Participation forms}

\section{Result And Discussion}

Community participation in community-based tourism program in Kelimutu National Park was symbolic, or in tokenism levels. Theoretically, this participation form was less invited community and stakeholders in ecotourism planning and development programs. In implementation, local community often invited to listen, accepted information, and finally requested for agreement. Participation only used as requirement of program approval, that indicated program has been made through consultation process, informing to the public and accepted by public. Based on the Structural Equation Modeling the symbolic participation was drawn in Fig. 1. 


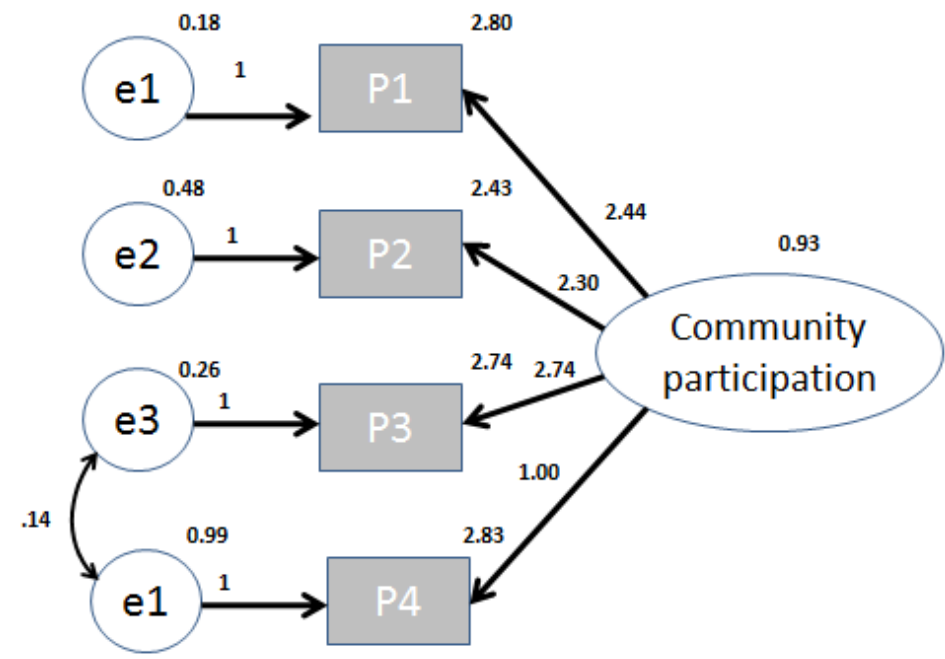

Fig. 1.The models of community participation in Kelimutu National Park. Notes:

P1: community involvement in planning, P2: community involvement in implementation, P3: community involvement in monitoring, and P4: community involvement in preservation

From the model, the planning variable has highest significant impact (0.872) compare to the variable of monitoring (0.856), implementation (0.723), and preservation (0.295). The value significantly shows that the participation aspect in ecotourism based on community in Kelimutu National Park was low. It is especially crucial to improve local people participation to the tourism in Kelimutu National Park. Basically, local people has been interact with their environment for long time, and the interaction often produce spectacular landscapebased local culture tradition which are important in tourism [15].

Officially the issues of community participation national park has been drawn in national park strategic planning and management (Table 1). The long term program for community development has organized into three term, namely short, medium and long term. There are specific objective in each term, but it is seems that community development becoming main agenda of the national park. Theoretically, if programs planning and execution has been drawn and implemented, there are outcomes of the program and activity. Basically it is observed in the changes of community prosperity status. If it is success to be fully implemented, the local people will becoming strategic partner for national park in numerous conservation programs [6]. This findings however, shows that the program seem to be need evaluated systematically because the indicator of community participation was low. The result of many programs has identified not significantly influence the status of community and fail in generating public support.

Table 1. Participation aspect in ecotourism management in Kelimutu National Park

\begin{tabular}{|c|c|c|}
\hline Term & Agenda & Strategy achievement \\
\hline $\begin{array}{l}\text { Short term } \\
(2009-2014)\end{array}$ & $\begin{array}{ll}\text { a. Strengthening community development and } \\
\text { local institution } \\
\text { b. Establishing document for community-based } \\
\text { management planning }\end{array}$ & $\begin{array}{l}\text { a. Accommodating local culture in } \\
\text { management } \\
\text { b. Establishing integrative-participative } \\
\text { buffer zone management planning } \\
\text { c. Strengthening capacity of young } \\
\text { generation, capacity building and coop } \\
\text { development }\end{array}$ \\
\hline $\begin{array}{l}\text { Medium } \\
(2014-2019)\end{array}$ & $\begin{array}{ll}\text { a. Improving local people prosperity through } \\
\text { optimizing role of Kelimutu National Park } \\
\text { b. Strengthening local community participation } \\
\text { in monitoring and development of elimutu } \\
\text { National Park }\end{array}$ & $\begin{array}{l}\text { a. Increasing local economic status } \\
\text { b. Improving knowledge and capacity } \\
\text { development of local community } \\
\text { c. Strengthening economic based ecotourism }\end{array}$ \\
\hline $\begin{array}{l}\text { Long term } \\
(2009-2029)\end{array}$ & $\begin{array}{l}\text { a. Improving local people prosperity through } \\
\text { optimizing role of Kelimutu National Park } \\
\text { b. Solving problems through participation } \\
\text { schemes }\end{array}$ & $\begin{array}{l}\text { a. Strengthening network to promote and } \\
\text { sell local produk in ecotourism market } \\
\text { b. Applying modern technology to support } \\
\text { local community development }\end{array}$ \\
\hline
\end{tabular}

Sources: Data analyzed from Kelimutu National Park document, 2009

This research found that the participation form of community in ecotourism development in Kelimutu Natonal Park was symbolic. It is similar with the participation concept of Arnstein (1969). As modeled in SEM diagram, the perspective of informant confirm the empirical realistic through the statement: 
"We are rarely included in programs, also not included in coordination. All of the planning has set up properly by staff from Kelimutu National Park. We only run all of the program which was declared by staff of the park. When staffs of the park prohibit community to cultivate crop in forest, we follow. If there are directions to work in forest, we just follow. If it is prohibited to cut tree, we just follow. We follow all of the direction. We already aware about the sustainability of forest because our ancestor teach us to conserve forest. We should continuously conserve forest for our generation, because forest is critical sites to provides our needs (Interview with EJP July, 2015).

These phenomena shows the practices of participation in Kelimutu national Park was low and tend to be symbolic. Local people participation has been indentified passive. Practice of participation only implemented to meet national park's obligation and park's agenda which area declared in working document of park. These fact was similar with the statement of most respondent, that people rarely $(16,9 \%)$ and not involved in natural resources management, especially natural resources management for ecotourism development in Kelimutu National Park (Table 2).

Table 2. Community participation in Kelimutu National Park management

\begin{tabular}{|l|l|l|}
\hline Management & $\mathrm{N}$ & $\%$ \\
\hline Never & 174 & 48.1 \\
\hline Rarely & 61 & 16.9 \\
\hline Sometimes & 57 & 15.7 \\
\hline Often & 59 & 16.3 \\
\hline Always & 11 & 3 \\
\hline
\end{tabular}

These perception shows that participation was very low, or the participation terminology of Arnstein (1969) it is classified as tokenisme or there also possible to be no participation.These participation form especially crucial to create the manipulation practices, and able to be exploitative. The implementation of participation programs only used to proposed which are looks discussed, informed and accepted by community. In fact there are no participation. Scholars point out that one of the limitation of community participation is the scenario and mechanism of community-based tourism development program [1] [2] [10]. In the perspective of community-based ecotourism implementation, these situation confirm the low of community position in some functions, including control and decision making functions to increase community benefits from ecotourism business. These situations basically show that ecotourism program in Kelimutu National Park fail to provide benefits for local people. In the implementation, there are gaps between the conceptual strategy for ecotourism as a tool to increase local economic benefits and the reality in the field.

\section{Impact of symbolic participation to tourism resources utilization and preservations}

Impact of the less participation lead to the utilization and preservation participations. Local community argues that the utilization of natural and cultural resources for tourism purposes was less. Similarly, the preservation participation was less. According to local people, utilization of resources for tourism was limited. Local people involved as small trader in attraction area, transportation service, guide and security staff.

Table 3. Community participation in park resources utilization in ecotourism program in Kelimutu National Park

\begin{tabular}{|l|l|l|}
\hline Utilization & $\mathrm{N}$ & $\%$ \\
\hline Never & 57 & 15.7 \\
\hline Rarely & 50 & 13.8 \\
\hline Sometimes & 189 & 52.2 \\
\hline Often & 44 & 12.2 \\
\hline Always & 22 & 6.1 \\
\hline
\end{tabular}

Table 3 shows that the majority of local people use natural resources as tourism attraction in minimal level $(81.7 \%)$. There may be related to complex aspect, ranging from regulation and capacity of the local people to uses natural resources sustainably. Most of the respondents claims that they sometimes involve in program $(52,2 \%)$, very rare to involve $(13,8 \%)$ and no involvement $(15,7 \%)$. This is clearly indicate that the participation of local people in Kelimutu National Park was low. This is also occurs in the maintenance of ecotourism resources and assets. The majority of respondent argues that community rarely involved in ecotourism asset management in Kelimutu National Park (81.5\%). Local community was involved if needed by program $(16.6 \%)$, and they was very rare to invite to the programs $(12 \%)$. Most of the $(53 \%)$ state that community rarely involve in management (Table 4). This figure shows that community involvement in maintaining park's asset was low. 
Table 4. Community participation in park maintenance in ecotourism program in Kelimutu National Park

\begin{tabular}{|l|l|l|}
\hline Maintenance & $\mathrm{N}$ & $\%$ \\
\hline Never & 192 & 53.0 \\
\hline Rarely & 43 & 11.9 \\
\hline Sometimes & 60 & 16.5 \\
\hline Often & 56 & 15.5 \\
\hline Always & 11 & 3 \\
\hline
\end{tabular}

Less of participation in use and maintenance of tourism assets in Kelimutu National park can be caused by internal aspect of institution of national park and the community which are resulting symbolic participation. Based on the interview data, the symbolic participation has create community has apathetic and reluctant to the management and development of tourism in Kelimutu National Park. In the perspective of respondent, some of them state that it is better not involve and people enjoy to work in paddy field and orchards. Join in many programs in park was unclear, and it is only ceremonial activity to officially generate public support.

\section{Impact of participation in attraction, accessibility and amenity preservation}

Beside provides significant impart to the community participation in uses and preserve natural resources, the symbolic participation also contribute to the low of community participation in protection of object attraction, accessibility and amnesty in Kelimutu National Park. The majority of local community provides less support of parks programs.

Table 5. Community perception to the protection programs of natural tourism object, accessibility and amenities in Kelimutu National Park

\begin{tabular}{|l|l|l|}
\hline Perception & N & $\%$ \\
\hline No support & 54 & 14.9 \\
\hline Less support & 178 & 49.2 \\
\hline Ordinary & 49 & 13.5 \\
\hline Support & 59 & 16.3 \\
\hline Strong support & 22 & 16.1 \\
\hline
\end{tabular}

As shown in Table 5, it is clear that the majority of respondents involvement in preservation was low (78\%). Most of the respondent provides negative respond to the preservation program statement. About (49,2\%) state less contribution in support preservation, $14,9 \%$ was not support all of the programs related to tourism development, especially in term of attraction, accessibility and amenity preservation. This also support the fact about symbolic participation in ecotourism development in Kelimutu National Park.

\section{Impact of participation in local community prosperity}

Symbolic participation has been observed in community participation in preserving object attraction, accessibility and amenity. This form of participation is also observed in the contribution of ecotourism programs in local economic status. It is observed that Kelimutu National park still unable to increase and contribute significantly in economic status of local people.

As shown in Table 6, the prosperity level of responded was medium and in many case tenet to decrease.

Table 6. Status of local community conditions after ecotourism program in Kelimutu National Park

\begin{tabular}{|l|l|l|}
\hline Community conditions & $\mathrm{N}$ & $\%$ \\
\hline Very poor & 14 & 3.9 \\
\hline Poor & 42 & 11.6 \\
\hline Moderate & 233 & 64.4 \\
\hline Good & 62 & 17.1 \\
\hline Very good & 11 & 3 \\
\hline
\end{tabular}

Table 6 shows that there are no significant economic contribution to the economy status of local people. Ecotourism seems to contributes less to local community prosperity. If these situation continuous in the future, the development of ecotourism is questionable. The concept and strategy implementation should be reevaluate and the roots problems of the community involvement fails should be identify. Scholars point out that such situation occurs due to lack of comprehensive planning in the beging of ecotourism development programs. It is observed that the ecotourism planning less in community involvement aspect and fail to identity community needs which area able to be provided by ecotourism program and activity in the park [7] [13] [16]. The symbolic participation seems to be culture, and it has been influence the bad perception of local community in ecotourism development planning. Since the symbolic participation, community shows low active participation Community apathetic to the national park programs. As shown in Table 8, the prosperity levels of community in mediums scale, an in some aspect the level of prosperity tend to poor. These data especially shows that 
symbolic participation not contribute to the local people prosperity. As a target of ecotourism development, there are no benefits generated by local people, both in term of individuals or group. Therefore, it is crucial for the management of Kelimutu National Park to improve the implementation of community-based ecotourism program [7] [8] [12].

Based on the research, it is concluded that:

\section{Conclusion}

1. From of local community participation in ecotourism program in Kelimutu National Park was symbolic. Local community only involved when their existence was needed. The participation only used as a formal requirement aspect for program approval, that programs seems has communicated, informed and approved by local community.

2. The symbolic participation contributes to the utilization and management of natural resources for tourism in Kelimutu National Park, in which there are no local community involvement in tourism program. This supported by the majority respondents argue that they are not included in resources utilization in ecotourism development. As an impact of limited involvement and natural resources utilization for ecotourism development in park, the contribution of ecotourism in Kelimutu National Park to the surrounding community was questionable. It seems that there are no contributions of tourism in local community prosperity, especially in economic aspect.

Based on the research finding, it is suggested that the implementation of ecotourism should be improved.

1. All of the stakeholders which area related to the tourism development, biodiversity conservation and local development should be in synergy and together countermeasure the practice of symbolic participation in the implementation of ecotourism in Kelimutu National Park.

2. Local government should become facilitators to drive the community based tourism implementation. Some aspect technically should be improved to achieve the objective of tourism development in Kelimutu National Park.

3. The park authority should be more cooperative and should be able to support participation in ecotourism implementation in Kelimutu National Park.

\section{References}

[1]. P.E. Murphy, Tourism A Community Approach (Longman London and New York, 1985).

[2]. S.J. Page and R.K Dowling, Ecotourism. Theme in Tourism (Prentice Hall, USA, 2001).

[3]. C. Fandeli and Mukhlison, Pengusahaan Ekowisata (Fakultas Kehutanan UGM, Yogyakarta, 2000).

[4]. C. Fandeli, Perencanaan Kepariwisataan Alam (Fakultas Kehutanan UGM, Yogyakarta, 2002).

[5]. Hakim, L. Dasar-dasar ekowisata (Bayumedia, 2004).

[6]. CJ. Stem, JP. Lassoie, DR., Lee, DD Deshler, and JW. Schelhas, Community participation in ecotourism benefits: The link to conservation practices and perspectives. Society \&Natural Resources, 16(5), 2003, 387-413.

[7]. D. Patin and J. Fracis, Community Based Sustainable Tourism (UWI-SEDU, UK, 2005).

[8]. L. Hakim, L. Planning for nature-based tourism in East Java: recent status of biodiversity, conservation, and its implication for sustainable tourism. ASEAN Journal on Hospitality and Tourism, 7(2), 2008, 155-167.

[9]. M. Baiquni and Susilawardana, Pembangunan Yang Tidak Berkelanjutan: Refleksi Kritis Pembangunan Indonesia (Transmedia Global Wacana, Yogyakarta, 2002)

[10]. C. Fandeli, Perencanaan Kepariwisataan Alam (Fakultas Kehutanan UGM Yogyakarta, 2002).

[11]. DJ. Timothy, Participatory Planning: a View of Tourism in Indonesia. Annals of Tourism Research. 26 (2), 1999, 27-40.

[12]. Wardianto and M. Baiquni. Perencanaan dan Pengembangan Pariwisata (Lubuk Agung. Bandung, 2011).

[13]. N. Hausler, Definition of Community Based Tourism (Tourism Forum International at The Reisepavillon, Hanover, 2005).

[14]. K. Monk, Y. De Fretes, and G. Reksodiharjo-Lilley, Ecology of Nusa Tenggara and Maluku (Tuttle Publishing, 2013).

[15]. L. Hakim, Cultural Landscapes of the Tengger Highland, East Java. In Landscape Ecology in Asian Cultures Springer Japan, 2011) pp. 69-82).

[16]. S.J. Page, Tourism Managemen, Managing for Change. Second Edition (Butterworth-Heinemann. USA, 2007). 